\title{
“THEN IBIS CAME": LADY HESTER PULTER'S UNPUBLISHED MANUSCRIPT IN ITS SOCIO-POLITICAL AND NORMATIVE CONTEXT ${ }^{1}$
}

\author{
Juan de Dios Torralbo Caballero ${ }^{2}$
}

\begin{abstract}
"Then Ibis Came": Lady Hester Pulter's Unpublished Manuscript in its Socio-Political and Normative Context

Abstract: This article focuses on the manuscript of Lady Hester Pulter, a bundle containing 130 sheets found in 1996 in Leeds by Mark Robson, containing two series of poems and another 30 pages of a romance. The main objective of this paper is to set forth the reasons spurring the writer not to disclose her literary work, by mapping out the cultural and socio-political milieu of her time. To this end, it first addresses various laws that were enacted to exert control over literature, such as the banning of plays, and decrees governing printed works; and pointing out some decisions of a political nature, such as the 1649 banishing of monarchists from the city. In this way Hester Pulter's creative legacy is placed in its context during the 1640s and 1650s, when political divisions radicalised, splitting the country into two factions at loggerheads, divided by severe ideological tension. Also examined are some family-related factors that may have persuaded the poet to keep her work secret, within the home and away from cultural and intellectual circles.
\end{abstract}

Keywords: Hester Pulter, Manuscript, Poems, Emblems, The Unfortunate Florinda.

"Then Ibis Came": El manuscrito inédito de Lady Hester Pulter en su contexto sociopolítico y normativo

Resumen: Este artículo se centra en el manuscrito de Lady Hester Pulter, un legajo de 130 folios encontrado en 1996 en Leeds por Mark Robson con dos series de poemas junto a otros 30 folios con un romance. El objetivo principal de este trabajo es mostrar las razones que motivaron a la escritora a no difundir su obra literaria cartografiando su el entramado cultural y socio-político de su época. Para ello en primer lugar se abordan las diversas leyes que fueron promulgadas sobre de control de la literatura tales como la prohibición de las representaciones teatrales y los decretos sobre la impresión de las obras, señalando algunos mandatos de corte político, como el de 1649 que expulsaba a los monárquicos de la ciudad. De esta manera se sitúa el legado de Hester Pulter en su contexto, durante las décadas de 1640 y 1650, cuando la división política se radicalizó dividiendo al país en dos facciones con una aguda tensión ideológica. Asimismo, se aducen algunas características de índole familiar, las cuales se deduce que aconsejaron a la poeta a mantener su obra en secreto, dentro de la esfera más puramente doméstica y alejada de los círculos culturales e intelectuales.

Palabras clave: Hester Pulter, manuscrito, poemas, emblemas, The Unfortunate Florinda.

1 Fecha de recepción: 10/12/2016.

Fecha de aceptación: 26/12/2016.

${ }^{2}$ Associate Professor, English and German Philology Department, English Literature, University of Córdoba; $\bowtie$ torralbocaba,llero@uco.es. 


\section{Introduction}

This work aims to identify and reflect upon the confluence of reasons why Hester Pulter (c. 1607-1678) never published her writing. No published version of these works have been found, nor written references to them, substantiating that Hester Pulter's works were not published and did not circulate in manuscript form in the intellectual circles of her time. According to Elizabeth Clarke "there is no evidence that her poems circulated" (Clarke 2005: 112). It is impossible to definitively conclude the reason for this decision, but it is possible to call attention to some of the likely causes. To this end, this paper explores the historical and socio-political circumstances of her time.

The year 1996 is key in the historiography of 17th-century English literature and the legacy of Hester Pulter, as in that year Mark Robson discovered a manuscript that had been incorrectly catalogued at the Brotherton Library at Leeds University, consisting of 130 pages of poems, along with another 30 pages of an unfinished romance (Clarke 2005: 111). The work interested Angel Chauncy, the grandson of the prominent antiquarian Sir Henry Chauncy, as studied by researchers Sarah Ross (2000: 162) and Elizabeth Clarke (2005, 111). Precisely the work of Henry Chauncy (1700, I: 141-7) is one of the indispensable sources to delve into the biography of the Pulters, as he devotes about seven pages to them, along with the diary of her brother-in-law: The Diary of John Harington (1977).

Some studies have been published since then, such as the pioneering work by Peter C. Herman (2010). 2014 is another watershed year, because in it Alice Eardley published her masterful Poems, Emblems, and The Unfortunate Florinda; its erudite and clear introduction, along with notes and a final glossary, make it required reading for all those studying the 17th-century writer. In 2016 Maureen E. Mulvihill (2016) disseminated her Pulter's work, justly dedicated to the memory of Margaret P. Hannay (1944-2016). 
Before investigating the reasons why Hester Pulter never published her work, it behoves us to take a good look at her body of work, consisting of two series of poems and an unfinished romance, and to indicate their thematic aspects.

\section{The works: two collections of poems and a romance}

Circa 1623 Hester Ley, the sixth daughter of James Ley (first Earl of Marlborough) and of Mary of Stoke Talmage, married Arthur Pulter (belonging to a wellto-do family from Hertfordshire), a Justice of Peace, Captain of the Militia and Sheriff in said locality. Arthur resigned from his position in around 1641 when the Civil War was about to begin, which has been interpreted as a way to distance himself from the political situation of the time. Elizabeth Clarke (2005: 113) speculates that "perhaps his resignation suggests he wished to stay neutral."

Hester and Arthur settled in the village of Broadfield, about 50 kilometres from London, where the poet composed her literature, immersed in the fortuitous seclusion of the place. Chauncy (1975: 1145) writes that "shortly after the breaking forth of the late civil War, declin'd all publick Imployment, liv'd a retired life, and thro" the Importunity of his Wife began to build a fair House of Brick upon this Mannor." Sarah Ross (2005: 1) wrote of "a kind of Royalist retirement at her county home of Broadfield."

In her biography her numerous offspring are worthy of special note: between 1624 and 1648 they had 15 children. Standing out as key themes in her work are pain over the loss of their children (they lost 13), loneliness, odes to the nearby nature, as well as domestic seclusion and rural refuge. Themes related to such rural refuge were employed by prominent writers like the Cavalier Poets, as can be appreciated in the works of Robert Herrick, Thomas Carew, Sir John Suckling, Richard Lovelace, Edmund Waller and Sir John Denham (Partridge 1966: 18). Her works of literature consists of two series of poems and a romance. Among the images these works evoke are a series related to modern science, cosmology and astronomy (Hutton 2008: 77), as well as the politics of her time. 
The "Poems Breathed Forth By the Noble Hadrassas" is a series consisting of 67 works containing landscape themes (like her garden in Broadfield and its wooded setting), domestic affairs and family (the death of her children, her loneliness, her illnesses), religious themes (over sin, and the body and soul) and political issues (such as the beheading of Charles I) in which she expresses overt positions (in favour of the monarchy and against Cromwell's side). This series of poems was written "between the mid-1640s and 1655" (Eardley 2014: 20).

The following verse (taken from the second poem, entitled "The Invitation into the Country, to M D.[ear] D.[aughters] M.[argaret] P.[ulter], P.[enelope] P.[ulter], 1647, When His Sacred Majesty Was at Unhappy [Holmby] “) (Pulter 2014: 48-56), provides an example ${ }^{3}$ of the aforestated. The poem depicts Hyde Park, associated with semantics of the monarchy (it was a place of leisure for the royal family; for example where the king hunted, as Charles opened it to the public in 1637), as the natural elements of the park are personified, and mourn the flight of Chloris, representing the wife of Charles I, Queen Henrietta Maria, who left England in 1644 for her native France, to avoid the dangers of the War (Eardley 2014: 49):

Hyde Park a place of chief delight, Her bushes mourn like Jews in white; The stately deer do weeping stray, Anticipating their last day.

Spring Garden, that such pleasures bred,

Looks dull and sad since Chloris fled.

The crystal Thames her loss deplores,

And to the sea her grief outroars;

The swans upon her silver breast

Though dying yet can find no rest,

But full of grief cry, "welladay,"

And singing, sight their breath away.

Ay me, then come, make haste away;

From that sad place make no delay. (23-36)

The series entitled "The Sighes of a Sad Soule Emblematically Breath'd Forth by the Noble Hadassas" comprises the second segment of her work, found in the manuscript,

\footnotetext{
${ }^{3}$ More examples contextualised within her political vein can be seen in the paper entitled "Hester Pulter'sPolitical DNA in her literature" (Torralbo 2017, 156-160).
} 
from page 90 to 130. This part of the manuscript consists of 54 emblems. These emblem poems follow the English tradition of Francis Quarles (1635) and George Wither (1635), but can be defined as "naked emblems" (Eardley 2014: 28) because, unlike the traditional ones, they lack a visual element serving as an introduction, as found in those by Quarles (1886: 16, 22) and Wither (1635: 1-50). Emblem 52 is included as an example, which begins, "The Caucasines who locusts were annoyed" (Pulter 2014: 260). The following excerpt alludes despectively and pejoratively to the head of the English Republic, Oliver Cromwell:

Then ibis came and did these worms destroy, But with his putrid filth he ten times more Afflicted them than they were e"er before. So this sad kingdom locusts did o"errum; Such clouds (ay me) as did eclipse our sun. (11-15)

The third segment of her work is "The Unfortunate Florinda" (1661), belonging to the tradition of the romance, as embodied by Arcadia (Sir Philip Sydney 1593) and Argenis (John Barclay 1621). This work, as demonstrated by Alice Eardley (2014: 3) "explores the balance and abuse of power in relationships between the sexes" and shows the author's "awareness of her own gender and in her sustained and far-reaching analysis of the social and political consequences of early modern gender relations." In fact, "the romance condemns all forms of tyranny and instead promotes the exercise of legitimate power based on mutual care and cooperation" (Eardley 2014: 32). The romance was written "between 1655 and 1662" (Eardley 2014: 21).

The writer's monarchical sentiment is modulated through her content, stanzaic form and narrative genre. In the poems one can detect numerous references to the monarchy and elements opposing the republic. For example, the emblem, as a form of literature, was considered monarchical in and of itself, while the romance represented a genre that in the 1650s "became particularly popular with royalists" (Eardley 2014: 30) such that it also transmitted political connotations. In this way the writer's selection of the emblem and romance denote her knowledge of the literary tradition. As Smulders (2014: 22) points out, she had in mind an educated and erudite reader. 
In contrast, the sequence of sonnets by John Milton is named, this writer representing Lady Hester Pulter's ideological opposite. The first five sonnets by John Milton, along with his sonnets in Italian, were published in his first volume of poems, in 1646 (Poems of Mr. Milton, both English and Latin, Compos'd at several times. Printed by his true Copies), while the complete work of poetry appeared in 1673. It proves instructive to compare Pulter's work with Milton's sonnets, due to the political content that both writers include and reflect upon in their writings. The two works contain clear political messages, but they are diametrically opposed. While Hester Pulter praises Charles, condemning his murder (e.g., in the eighth poem: "On That Unparalleled Prince Charles the First, His Horrid Murder") (Pulter 2014: 77-79), John Milton upholds and praises Oliver Cromwell in his Sonnet 17, entitled "To the Lord Generall Cromwell May 1652" (Milton 1980: 82).

The publication of political sonnets was not common in 17th-century English literature. The literary corpus of John Milton is better understood by placing it in the context of his fervent Puritan and republican ideology. In addition, the lineage of his work is related to Italian literature, specifically to the flexibility introduced by Giovanni della Casa (author of Il Galateo), who "emancipated the Italian sonnet from a framework that had become too rigid" (Honingman 1966: 41) and Torquato Tasso (author of Gerusalemme liberata), with the expression of political themes. In this way they diverged from the English archetype, characterised by the themes of love and of the Divine, as in the works of Sir Philip Sidney, John Donne and George Herbert. The "apostrophic sonnets" (Hall 2007: 101) by John Milton are dedicated to the figures and achievements of Cromwell and Fairfax, while Hester Pulter dedicated poems to Charles I and other military figures of the time.

\section{The ban on theatre performances: "[P]ublic stage plays shall cease and be forborn"}

On 2 September, 1642, when the English Civil War was commencing, the House of Commons issued a decree prohibiting theatrical performances ("spectacles of pleasure, too commonly expressing lascivious mirth and levity"): 


\begin{abstract}
Whereas the distressed state of Ireland, steeped in her own blood, and the distracted estate of England, threatened with a cloud of blood by a civil war, call for all possible means to appease and avert the wrath of God appearing in these judgements; among which fasting and prayer having been often tried to be very effectual, have been lately and are still enjoined; and whereas public sports do not well agree with public calamities, nor public stage plays with the seasons of humiliation, this being an exercise of sad and pious solemnity, and the other being spectacles of pleasure, too commonly expressing lascivious mirth and levity; it is therefore thought fit and ordained by the Lords and Commons in this Parliament assembled that, while these sad causes and set times of humiliation do continue, public stage plays shall cease and be forborn; instead of which are recommended to the people of this land the profitable and seasonable considerations of repentance, reconciliation and peace with God, which probably may produce outward peace and prosperity and bring again times of joy and gladness to these nations.
\end{abstract}

The Parliament, thus, ordered the closing of the theatres. On February 11, 1648 another law was promulgated that limited performances even more severely than the 1642 law. The February 1648 was entitled: "An Ordinance for the utter suppression and abolishing of all Stage-Plays and Interludes, within the Penalties to be inflicted on the Actors and Spectators therein expressed" (Firth and Rait 1911: 1070-1072) and stated that:

Whereas the Acts of Stage-Playes, Interludes, and common Playes, condemned by ancient Heathens, and much less to be tolerated amongst Professors of the Christian Religion is the occasion of many and sundry great vices and disorders, tending to the high provocation of Gods wrath and displeasure, which lies heavy upon this Kingdom, and to the disturbance of the peace thereof; in regard whereof the same hath been prohibited by Ordinance of this present Parliament, and yet is presumed to be practised by divers in contempt thereof. Therefore for the better suppression of the said Stage-playes, Interludes, and common Players, It is ordered and ordained by the Lords and Commons in this present Parliament Assembled, and by Authority of the same, That all Stage-players and Players of Interludes and common Playes, are hereby declared to be, and are, and shall be taken to be Rogues, and punishable, within the Statutes of the thirty ninth year of the Reign of Queen Elizabeth, and the seventh year of the Reign of King James, and liable unto the pains and penalties therein contained, and proceeded against according to the said Statutes, whether they be wanderers or no, and notwithstanding any License whatsoever from the King or any person or persons to that purpose. 
The law also included a section indicating how to deal with actors who were caught engaging in theatre performances, and even the attendees, who, once caught at theatres, had their money seized and handed over to the poor through parish officers of the Anglican church ("Moneys gathered of persons coming to see Stageplayes shall be forfeited and be paid to the Churchwardens for the poor") ${ }^{4}$.

The coercive environment the Parliamentarians generated is reflected in the proclamations against theatres, such as this anonymous one, which confirmed that: "[...] we need not any more Stage-playes; we thanke them for suppressing them, they save us money [...] "5 (Egan 2014: 114). There were more realistic elements, however; in 1648, they questioned the Puritans" proposal to rescind holidays: "[...] have not they reason to suppress all Holly-dayes instituted formerly by the Church for the service of God, and for some refreshment to young people? What need is there of any Playes? will not these serve well enough, especially when they have got Hillyar Swansted the Player to be one?"6 (Egan 2014: 114).

\section{The censorship of books: imprimatur}

In 1530 Henry VII decreed the review of books written in English before their publication. In 1538 the Privacy Council was to grant its imprimatur before a book could be printed and distributed. In 1586 another law was enacted that prohibited "the printing of any book until it had been licensed by the Archbishop of Canterbury or the Bishop of London." The procedure was described as follows: "The stationer brings the copy to one of the bishop's chaplains. On the manuscript itself, the latter indicates that the copy may be printed - authorizes or licenses the copy, that is. The stationer then brings the

\footnotetext{
${ }^{4}$ It may be viewed online, on the webpage entitled BHO British History Online, under "Acts and Ordinances of the Interregnum, 1642-1660," thanks to the Institute of Historical Research and the History of Parliament. See, specifically: http://www.british-history.ac.uk/no-series/acts-ordinancesinterregnum/pp1070-1072.

${ }^{5}$ Anonymous, A Key to the Cabinet of the Parliament, By Their Remembrancer, B1v. Cited by Egan (2014, 114).

${ }^{6}$ Anonymous, A Key to the Cabinet of the Parliament, By Their Remembrancer, Wing K387 ([London]: n. pub., 1648), A3r. Cited by Egan (2014, 114).
} 
manuscript to the Stationer's Hall. The Warders peruse the copy [...]"' (Kirschbaum 1955, 36).

On July 11, 1637 a decree was promulgated "to reinforce and supplement rather than to supersede the earlier enactment, whose provisions had been found by experience to be defective in some particulars." H.S. Bennet (1970: 46) confirms that "All books and pamphlets, including all incidental matter in them, are to be lawfully licensed and authorized and duly "entered into the Registers Book of the Company"." Each type of writing had its own censors; for example, History books were to be approved by "one of the Principal Secretaries of State" while books of Poetry were to be approved "by the Archbishop of Canterbury or the Bishop of London".

On July 11, 1637 the "Decree of Star-Chamber Concerning Printing" was also enacted, by which the manuscripts were to be subjected to censorship before going public, in force until its abolition on July 5, 1641. Although the "Act against dissolving the Parliament without its own consent", of May 5, 1641, called for freedoms, and specifically the freedom of the press, the truth is that "these rights and, above all, freedom of the press, were conceived based on the interests of guilds and estates" (Carrillo 2011: xxv). H. S. Bennet (1970: 49) concluded that: "when the control was at its height between 1630 and 1640 'the imprimatur affected little more than a third of the books.",

In the 1640s the approval was granted by the Company of Stationers, according to the Order of June 13,1643, which Marc Carrillo calls an "extension of the Decree of 11 July, 1637". In 1643 Parliament "tried to re-impose order in the book world by prohibiting all unlicensed publications" (Herman 2011: 222). In response John Milton composed Areopagitica, which, was published on November 28, 1644 without permission. The work constituted a reply to the Parliament with a defence of the freedom of the press (Carrillo 2011: 11). It should be noted that John Milton adopted a series of political stances during his time, openly supporting the Republic under Cromwell and opposing the divine absolutism of Charles I. The content of this work, however, reveals that the writer (who was the Secretary for Foreign Tongues under Cromwell's government) did not agree with some measures of this political regime. 
Puritanical theocracy did not approve of publications or works of art that were intended to generate purely aesthetic pleasure. Rather, the republicans only sanctioned literature that paved the way for faith and towards human salvation, such as John Bunyan's The Pilgrim's Progress, and John Milton's poetic masterpiece Paradise Lost, works reflecting the Puritans" ideological conceptions (Ezell 2017: 3), though they were published in the period following the restoration of the monarchy.

On 20 December, 1649 the Printing Act was approved, considered as "the most comprehensive regulation of the British press in the 17th century, limiting the trade of printing to the city of London and its universities", as studied by María Nieves Saldaña Díaz (2007: 222). On January 7, 1653 another Printing Act was passed, augmenting control over publications, and remaining in effect until April of that year, when Cromwell's Protectorate began. This new era saw the application of the licensing system governed by the law of 28 August, 1655, which stipulated the existence of three Commissioners (Colonel John Barkstead, Alderman John Dethick and George Foxcroft), responsible for approving all the publications, to last until the end of 1659.

\section{The expulsion of the monarchists: "[A]ll persons who have engaged for the King [...] to depart the City"}

The country was fragmented into two distinct factions, each embracing utterly divergent ideological and political positions. On one side were the Parliamentarians (or Roundheads, thus dubbed for John Milton's haircut, as can be appreciated in the famous engraving by William Faithorne from 1670), led by Republican Oliver Cromwell and his followers. On the other side were the monarchists, or "Cavaliers" (a term stemming from the Spanish caballero, or gentleman), supporters of King Charles I. The clashes between these two radically conflicting sides generated sparks that eventually lit the fuse of the English Civil War.

The English Civil War must be understood as a series of military confrontations. The first Civil War (Morgan 2009: 317) began in August of 1642 and ended in October 
of 1646. Squaring off were troops led by Robert Devereaux, Earl of Essex, and Sir Thomas Fairfax, against the army headed up by Prince Rupert, "son of Frederick of Bohemia and James's daughter, Elizabeth" (Herman 2011: 216). Key clashes came at the Battle of Edgehill (1643) and the Battle of Naseby (1645) in which Cromwell and Sir Thomas Fairfax, with his New Model Army, defeated the Royalists under the command of the young but experienced Prince Rupert in October of 1646, when Oxford surrendered. As there was no national, centralised military force, the two sides "organized their armies through local militias and regional forces, commanded by local leaders or aristocrats. One of the cavalry colonels [...] was Oliver Cromwell” (Herman 2011: 219).

From 1649 to 1660 there was what historian Kenneth O. Morgan (2009: 325) has called a "revolutionary period". King Charles I was overthrown and the monarchy was abolished by the House of Lords and the Anglican Church. The king was subsequently executed, on January 30, 1649, on the scaffold in Whitehall, in what was a public spectacle, and England became a republic.

In 1649 Member of Parliament Thomas Fairfax promulgated a special command in which he orders allies of the monarch to abandon the city in less than 24 hours: $A$ Proclamation of His Excellency: tho. L. Fairfax, L. Gen. requiring all persons who have engaged for the King in the first of latter warres now in London, to depart the City, and ten miles distant therefrom, within twenty foure houres after the publication hereof. Six years later Republican leader Oliver Cromwell also issued a directive, instructing supporters of the king, and their children, to abandon the city by 5 November, 1655: By the Protector an order and declaration of His Highness, by the advice of His council, commanding all persons who have been of the late Kings party, or his sons, to depart out of the cities of London and Westminster, and late lines of communication, on or before Monday the fifth of November, 1655.

Once the monarchy was abolished the Parliament enacted a law making England a commonwealth (An Act Declaring and Constituting the People of England to be a Commonwealth and Free-State). This was followed by Oliver Cromwell's personal rule, termed the Protectorate (from December of 1653 until his death in September of 1658), 
during which he oversaw England as Lord Protector and Head of State (Morgan 2009: 327). When Oliver Cromwell died, his son Richard Cromwell took over the reins of the government, becoming Lord Protector and serving from 3 September, 1658 until 25 May, 1659. Morgan (2009: 329) notes that "his son lacked his qualities and succumbed to the jealousy of the senior military commanders," thereby leading to "the disintegration of the army." A year and a half after the death of Oliver Cromwell, "one section of the army under General Monck decided that enough was enough. Free elections were held and Charles II was recalled." The following year the son of the beheaded Charles returned, and was crowned the new King of England (Charles II), thereby restoring the monarchy. This arrival was recorded by writer Samuel Pepys (1893: 161-162) in his Diary; specifically, in his entry on Friday, May 25:

By the morning we were come close to the land, and every body made ready to get on shore. [...] Great expectation of the King's making some Knights, but there was none. [...] and so got on shore when the King did, who was received by General Monk with all imaginable love and respect at his entrance upon the land of Dover. Infinite the crowd of people and the horsemen, citizens, and noblemen of all sorts. The Mayor of the town came and gave him his white staff, the badge of his place, which the King did give him again. The Mayor also presented him from the town a very rich Bible, which he took and said it was the thing that he loved above all things in the world. [...] The shouting and joy expressed by all is past imagination.

Pepys's account, lying somewhere between literature and history, portrays the joy with which Charles II was received upon his arrival on the English coast, after his exile during the war. Poems on the Restoration have not been found in Hester Pulter's manuscript. Alice Eardley (2014: 21) writes that "surprisingly, given the vehement royalism that Pulter voices in her poems, there are no poems referring to the Restoration of Charles II in 1660, although it is possible there were poems that have not survived, or that have yet to be found." The poems “The Weeping Wish, January 1665," "The Hope, January 1665" and "Made When My Spirits Were Sunk Very Low with Sickness and Sorrow", May 1667, I Being [61] Years Old" suggest that Hester Pulter wrote poems circa 1660, as noted by Alice Eardley in her "Introduction." 


\section{Possible family reasons}

Hester Pulter's family members harboured opposing ideologies, in addition to less strident positions than those she took, at least in her literary work. As mentioned, her husband Arthur Pulter left his post as sheriff and took up residence at his impressive manor Broadfield. According to Alice Eardley (2014: 15) it "would appear that until his death nearly half a century later he declined to take part in the local or national governmental responsibilities that would have been expected of a man of his class." As noted, this voluntary seclusion has been interpreted by some as evidencing his desire to remain neutral regarding the social and political issues of the time.

Her brother-in-law James Hobson (her sister Margaret's husband) was an ardent Parliamentarian and, as such, hostile to the writer's monarchical ideology. In the early 1640s this couple lived on Aldersgate Street, near their friend John Milton. In fact, Margaret Ley is mentioned in Milton's "sonnet X. To the Lady Margaret Ley" (Milton 1980, 79-80). Her brother-in-law John Harington (the husband of her sister Dionysia) changed his political stance from royalism to republicanism, and he eventually went on to be elected a Member of Parliament representing the District of Somerset. Harington was the son of a godson of Elizabeth I who translated Orlando Furioso (1591) into English (Eardley 2014: 17).

Alice Eardley (2014: 18) observes that "Pulter's engagement with her family would appear to conflict with the vehemently royalist tone of her literary manuscript" and that "during the 1640s, the majority of Pulter's closest relatives were, at points, in active opposition to the King." Given these ideological discrepancies in her family, upon the couple's retirement to their rural mansion, it is entirely understandable that the writer chose not to circulate her writings amongst friends and in intellectual circles. There are no documents alluding to the work of Hester Pulter (Clarke 2005: 112).

In addition to these factors, her predicament as a woman writer must also be mentioned; at a time when the literary scene was dominated by male writers, a woman who decided to publish, and openly voice her personal convictions was frowned upon. A 
case in point is the derision suffered by professional writer Aphra Behn ${ }^{7}$ (FigueroaDorrego 1999, 14, 19) during the Restoration. However, other female poets who chose to write manuscripts and to share them with their family members and small circles of friends (like Katherine Philips), or women writers who wrote conduct books and autobiographies (Delany 1969: 158-166) enjoyed good reputations. Examples of women writers of autobiographies include the Duchess of Newcastle, Mary Penington, Lady Fanshawe, Ann Lady Halkett and Mary Countess of Warwick, Lucy Hutchinson, who wrote books intended to serve as moral and ethical examples for their families and posterity.

\section{Conclusions}

Hester Pulter composed her poems from 1645-1655. In light of the decrees and laws curtailing free expression and suppressing publications (The Printing Acts of 1649 and 1653) and the control exercised by the Commissioners (1655-1659) during the Protectorate, it may be deduced that Hester Pulter opted not to publish her works for political reasons. To this can be added the ban on theatre performances enacted in February of 1648 (modifying that from 1642), and the 1649 proclamation urging monarchists to abandon the city in less than 24 hours. Family reasons must also be cited, including her husband's discretion with regard to political affairs, and the proParliamentary sympathies of her brothers-in-law James Hobson and John Harington.

Therefore, it may be inferred that Hester Pulter elected not to publish her work due to the political and social tension gripping the country during her era, characterised by the dichotomisation of English society; the tight control exerted over literature by rulers at that time; and the fact that her family included members who, unlike she,

\footnotetext{
${ }^{7}$ Ian Mortimer $(2017,395)$ in his book The Time Traveler'sGuide to Restoration Britain., establishes that Behn is "A woman of striking originality, who treads a delicate line between conformity (so as not to threaten the establishment too much) and revolutionary ideas".
} 
supported the Parliamentary faction. To all of this must be added the fact that she was a woman, with all the limitations this entailed, though she did belong to the upper class.

As a result, Hester Pulter's literature, composed during the Republican interregnum, was not disclosed in its manuscript form, nor was it ever printed. The 1640s was a time of warfare, and the 1650s was a period during which freedoms were curtailed. Thus, it was hardly an opportune moment to circulate or publish a work that openly favoured and defended the monarchy.

\section{References}

Bennet, H. S. 1970. "The Regulation of the Book Trade." English Books and Readers 1603 to 1640. Ed. H. S. Bennet. Cambridge: Cambridge University Press. 40-58.

Carrillo, Marc. 2011. "Estudio preliminar.” John Milton, Auropagítica. Joan Curbet, ed. Madrid: Tecnos. I-LXXXI.

Chauncy, Henry. 1975. The Historical Antiquities of Hertfordshire. Dorking: Kohler and Coombes.

Clare, Clare. 2004. "Theatre and Commonwealth." The Cambridge History of British Theatre. Eds. Jane Milling and Peter Thomson. Cambridge: Cambridge University Press. 458-476.

Clarke, Elizabeth. 2005. "Hester Pulter's "Poems Breathed Forth by the Nobel Hadassas." Early Modern Women's Manuscript Poetry. Eds. Jill Millman, Seal, Jill and Gillian Wright. Manchester: Manchester University Press. 111-127.

Delany, Paul. 1969. British Autobiography in the 17th Century. London: Routledge and Kegan Paul.

Eardley, Alice. 2014. "Introduction." Lady Hester Pulter, Poems, Emblems, and the Unfortunate Florinda. Ed. Alice Eardley. Toronto: Centre for Reformation and Renaissance Studies, 1-38.

Egan, Gabriel. 2014. "The Closure of the Theatres". Yearbook of English Studies, vol. 44: 103-119.

Ezell, Margaret. J. M. 2017. The Later Seventeenth Century. The Oxford English Literary History. Volume V. 1645-1714. Oxford: Oxford University Press.

"February 1648: An Ordinance for the utter suppression and abolishing of all Stage-Plays and Interludes, within the Penalties to be inflicted on the Actors and Spectators 
therein expressed." Acts and Ordinances of the Interregnum, 1642-1660, ed. C. H. Firth and R. S. Rait (London, 1911): 1070-1072. British History Online. Web. [10 January 2016].

Figueroa- Dorrego. Jorge. 1999. Aphra Behn (1640-1689). Madrid: Ediciones del Orto.

Firth, C. H. and R. S. Rait, eds. 1911. Acts and Ordinances of the Interregnum, 16421660. London: Published by His Majesty's Stationery Office. Printed by Wyman and Sons, Limited, Fetter Lane.

Hall, F. R. 2007. "Milton's Sonnets and his Contemporaries." The Cambridge Companion to Milton. Ed. Dennis Danielson. Cambridge: Cambridge University Press, 98-112.

Harington, John. 1977. The Diary of John Harington, M. P. 1646-53: With Notes for his Charges. Ed. Margaret F. Stieg. Somerset: Record Society.

Herman, Peter C. 2010. "Lady Hester Pulter's "The Unfortunate Florinda": Race, Religion and the Politics of Rape." Renaissance Quarterly, vol. 63: 1208-1246.

. 2011. A Short History of Early Modern England. British Literature in Context. Oxford: Willey-Blackwell.

Honingman, E. A. J. 1966. “General Introduction”. Milton's Sonnets. London: MacMillan, 29-81.

Hutton, Sarah. 2008. "Hester Pulter (c. 1596-1678). A Woman Poet and the New Astronomy”. Etudes Epistémè, vol. 14: 77-87.

Kirschbaum, L. 1955. Shakespeare and the Stationers. Ohio: Columbus.

Milton, John. 1980. The Complete Poems. Gordon Campbell, ed. London: J M Dent and Sons Ltd.

Morgan, Kenneth O. 2009. The Oxford Illustrated History of Britain. Oxford: Oxford University Press.

Mortimer. Ian. 2017. The Time Traveler's Guide to Restoration Britain: A Handbook for Visitors to the Seventeenth Century: 1660-1699. New York: Pegasus Books.

Mulvihill, Maureen E. 2016. "The Book of Hester. Editing an Uncannonical Text. Lady Hester Pulter: Brotherton MS Lt q32, Leeds UK.” Old Books / New Editions. Part II of III.

Partridge, A. C. 1966. The Tribe of Ben. Pre-Augustan Classical Verse in English. London: University of South Carolina Press.

Pepys, Samuel. 1892. Diary. The Diary of Samuel Pepys, Vol I. Ed. Henry B. Weatley. London: George Bell and Sons York 
Pulter, Hester. 2014. Poems, Emblems, and the Unfortunate Florinda. Alice Eardley, ed. Toronto: Centre for Reformation and Renaissance Studies.

Quarles, Quarles. 1886. Quarles's Emblems. London: James Nisbet.

Robson, Mark. 2004. "Pulter, Lady Hester (1595/6-1678)." Oxford Dictionary of National Biography. Lawrence Goldman, ed. Oxford.

Ross, Sarah. 2000. Women and Religious Verse in Early Manuscript Culture c. 16001668. Doctoral Dissertation. Oxford.

Ross, Sarah. 2005. "“Tears, Bezoars and Blazing Comets,' Gender and Politics in Hester Pulter's Civil War Lyrics." Literature Compass, vol. 2.1: 1-14.

Saldaña Díaz, María Nieves. 2007. "Libertad de prensa y energía política en la Areopagítica de John Milton.” Revista Internacional de Pensamiento Político, vol. 3: 211-235.

Smulders, Claire. 2014. "I to Solitude am still confind." Confinement and Resistance in Lady Hester Pulter's Poetry. Leiden University. Master Thesis supervised by Nadine Akkerman.

Torralbo Caballero, Juan de Dios. 2017. "Hester Pulter's Political DNA in her Literature". Central European Political Science Review, vol. 17.66: 154-167.

VV. AA. 1816. Librorum impressorum qui in museo Britannico adservantur Catalogus, Volumen 2. London.

Wither, George. 1635. A Collection of Emblemes, Ancient and Moderne [...]. London: Printed by A. B. for Henry Taunton. 